\title{
Cover Crops Management in the Soybean-Wheat Offseason
}

\author{
Lucas Link (Corresponding Author) \\ Federal University of Technology - Paraná (UTFPR), Brazil. \\ Email: lucas_tlink@hotmail.com \\ Vanderson Vieira Batista \\ Federal University of Technology - Paraná (UTFPR), Brazil. \\ Email: vandersonvbatista@hotmail.com \\ Paulo Fernando Adami \\ Federal University of Technology - Paraná (UTFPR), Brazil. \\ Email: pauloadami@utfpr.edu.br
}

Luara Silva Pereira

Federal University of Technology - Paraná (UTFPR), Brazil. Email: silvap.luara@gmail.com

Karine Fuschter Oligini

Federal University of Technology - Paraná (UTFPR), Brazil.

Email: karine_oligini@hortmail.com

Paulo Cesar Conceição

Federal University of Technology - Paraná (UTFPR), Brazil. Email: paulocesar@utfpr.edu.br

Received: May 21, $2020 \quad$ Accepted: June 9, $2020 \quad$ Published: June 17, 2020

doi:10.5296/jas.v8i3.17074 URL: https://doi.org/10.5296/jas.v8i3.17074 


\section{Abstract}

More than 2 million hectare of soil at the soybean-wheat offseason remains on fallow in Brazil. Therefore, this research studied a suitable cover crop and its herbicide management to be adopted is this period as well as its influence on wheat yield at the 2017/18 and 2018/19 growing season. Experiment was laid out as a randomized block design in a factorial scheme composed of four cover crops (Fagopyrum esculentum, Crotalaria juncea, Pennisetum glaucum and Urochloa brizantha) and two herbicide management [Anticipated Desiccation (17 days before) and Desiccation at the wheat Sowing day] with four replications. Fallow without cover crops was used as a control. The tradeoff between the additional biomass produced by millet and brachiaria between herbicide desiccation periods does not pay the wheat grain yield reduction, suggesting that its herbicide management should be anticipated. In the other hand, $C$. juncea showed a linear increase in biomass along the periods without wheat yield effects and its herbicide dissection at the wheat sowing day appears to be the best management. F. esculentum showed the fastest development cycle and can be recommended for shorter offseason periods. $P$. glaucum showed rapid growth and the highest biomass yield at both years, standing out as the best option for offseason periods from 70 to 80 days, although, anticipated herbicide management before wheat sowing resulted in higher grain yield at the second year of study. Further studies should consider other cover crop benefits as weed suppression, physical and chemical soil traits improvements and erosion reduction.

Keywords: Herbicide management; Fagopyrum esculentum, Crotalaria juncea, Pennisetum glaucum, Urochloa brizantha

\section{Introduction}

Among several cropping arrangement and soil use management options, soybean/wheat rotation under no-till are the most common adopted cash crop system in southern Brazil. Soybean is harvested between February and March and wheat is sown between May and June, generating an offseason that ranges from 70 to 120 days. These areas remain most of the times on fallow.

Low biomass of quickly decomposition from soybean residue added to great soil disturbance at wheat sowing process (17 cm row spacing) associate with intense rainfall amounts at May has prone the soil to great erosion problems. Thus, fallow is suitable for weed emergence which usually turn out in a greater problem on wheat fields, resulting in an increase in herbicide use.

In the other hand, according to Rosolem et al. (2016), selection of a suitable cover crop for rotation with grain crops is important and essential for the success of no-till, particularly in tropical soils. In this away, cover crops growth in the soybean-wheat offseason could reduce these problems, besides improving the physical, chemical, and biological soil traits, which may result in higher yields of subsequent crops (Pacheco et al., 2011; Rosolem et al., 2016; Posse et al., 2018; Büchi et al., 2018).

In this way, research and selection of a suitable cover crop for this offseason is very important in a way to allow benefits for the system. Moreover, considering the short length of time of 
this period, cover crop management at wheat sowing day would improve its dry matter yield, although, the role of grasses and legumes in this ecosystem may affect or not wheat yield potential. Due to it, beyond studying cover crop species biomass accumulation over time, this research aimed to study its herbicide desiccation management (17 days prior and at the day of wheat sowing) to better understand the tradeoff between the additional biomass produced between herbicide desiccation periods and its effects on wheat development and grain yield.

\section{Methods}

Research evaluated cover crops dry matter and wheat yield at the 2017/18 and 2018/19 growing seasons and, therefore, is presented in study 1 (which consider the cover crop phase) and study 2 (wheat phase). Climatological variables were measured by the climatic station of the campus.

\subsection{Experimental Design}

Study 1 (cover crops phase) was allocated to the experimental field in a randomized block design in a 4 x 5 factorial scheme, with four replications. Factor A refers to four cover crops [Urochloa brizantha cultivar Xaraés (brachiaria), Pennisetum glaucum cultivar ANm 38 (pearl millet), Fagoryrum esculentum cultivar IPR Baili (buckwheat) and Crolaria juncea cultivar IAC-KR (sunn hemp)] and factor B refers to five periods of evaluation along its development. Each experimental plot consisted of $4.5 \mathrm{~m}$ wide with $40 \mathrm{~m}$ long, totaling 180 $\mathrm{m}^{2}$.

At study 2 (wheat phase), experimental plots were subdivided ( $20 \times 4.5 \mathrm{~m}$ ) to establish the herbicide desiccation management arranged in a $5 \times 2$ factorial scheme, with four replications. Factor $\mathrm{A}$ is represented by the cover crops and fallow and factor B by herbicide dissection management so on called as anticipated desiccation and desiccation immediately before sowing respectively.

\subsection{Experimental Establishment and Management}

Experiment was carried out at Federal Technological University of Paraná, campus of Dois Vizinhos, Agricultural Research Station, located at $25^{\circ} 41^{\prime} 72^{\prime \prime}$ latitude south and $53^{\circ} 05^{\prime} 45^{\prime \prime}$ longitude west. According to Koppen's classification, the climate is Cfa, with an annual average rainfall of $2044 \mathrm{~mm}$. Soil at experimental site is classified as a Clayey Oxisol with an average altitude of $522 \mathrm{~m}$.

Cover crops were established after a soybean crop at different fields between growing seasons. At the first growing season (2017/18), drought conditions delayed soybean sowing and its harvest occurred on March $03^{\text {rd }}$ of 2018 . At the $2^{\text {nd }}$ growing season, soybean was sowed early (October $1^{\text {st }}$ of 2018) and harvested on February $02^{\text {nd }}$ of 2019 (more usual date). These dates are important since cover crops were sowed on the same day as soybean was harvested. Seeding was performed using a continuous flow seed-drill with $34 \mathrm{~cm}$ row spacing and sowing depth of $2 \mathrm{~cm}$, without fertilization. Regarding to the seed sowing density, were used: $13,25,45$, and $24 \mathrm{~kg} \mathrm{ha}^{-1}$ of brachiaria, sunn hemp, buckwheat, and pearl millet respectively. 
Cover crops herbicide desiccation management occurred on May $11^{\text {th }}$ and $28^{\text {th }}$ and May $10^{\text {th }}$ and $27^{\text {th }}$ respectively for the $1^{\text {st }}$ and $2^{\text {nd }}$ growing year. Glyphosate $\left[1,000 \mathrm{~g} \mathrm{ha}^{-1}\right.$ active ingredient (a.i)] associated with $6 \mathrm{~g}$ a.i ha ${ }^{-1}$ of metsulfuron-methyl were used in both growing season (2017/18 and 2018/19 years). Wheat cultivar TBIO Toruk® was sowed in both years with the aid of continuous flow seed-drill with $17 \mathrm{~cm}$ row spacing and $2.5 \mathrm{~cm}$ sowing depth with a seed density of $150 \mathrm{~kg} \mathrm{ha}^{-1}$ or 450 seeds per square meter.

Wheat fertilization was carried out according to the recommendation of the CQFS (2004) for meeting an expected yield of $5 \mathrm{t} \mathrm{ha}^{-1}$ and according to the average values found in the soil analysis in the 0.0-10.0 cm layer: $\mathrm{pH}(\mathrm{CaCl} 2) 5.1$; phosphorus $(\mathrm{P}) 16.2 \mathrm{mg} \mathrm{dm}^{-3}$; potassium (K) $0.3 \mathrm{cmol}_{\mathrm{c} \mathrm{dm}}{ }^{-3}$; organic matter $(\mathrm{OM}) 4.6 \mathrm{~g} \mathrm{~kg}^{-1}$; base saturation $59.3 \%$; cation exchange capacity of $13.2 \mathrm{cmol}_{\mathrm{c}} \mathrm{dm}^{-3}$; and, clay content of $53 \mathrm{~g} \mathrm{~kg}^{-1}$. Base fertilization was performed adding $208 \mathrm{~kg} \mathrm{ha}^{-1}$ of chemical fertilizer 16-36-00 (DAP) (33.3 $\mathrm{kg} \mathrm{ha}^{-1}$ of $\mathrm{N}$ and $74.9 \mathrm{~kg} \mathrm{ha}^{-1}$ of $\mathrm{P}_{2} \mathrm{O}_{5}$ ). Topdressing fertilization at initial tillering was performed applying $180 \mathrm{~kg} \mathrm{ha}^{-1}$ of the fertilizer mixture 13-00-28 (YaraBela + potassium chloride) $(23.4 \mathrm{~kg}$ ha of $\mathrm{N}$ and $50,4 \mathrm{~kg}$ ha $\mathrm{K}_{2} \mathrm{O}$ ) and at the plenty of tillering with $95 \mathrm{~kg} \mathrm{ha}^{-1}$ of the formula 46-00-00 (43.7 $\mathrm{kg} \mathrm{ha}^{-1}$ of $\mathrm{N})$. Weed, pests, and disease management were carried out based on scouting, applying agrochemicals according to the technical recommendations (Brazilian Agricultural Research Corporation - Embrapa) (Pires and Vargas, 2014).

In the specific management of weeds, in the fallow plots, $700 \mathrm{~g}$ ai ha $\mathrm{h}^{-1}$ of 2,4-D was applied for control of volunteer soybean plants at April. At the wheat tillering phase, $645 \mathrm{~g}^{\mathrm{a} . \mathrm{i} \mathrm{ha}} \mathrm{h}^{-1}$ of 2,4-D was applied. As the buckwheat seed bank re-infested the area, another herbicide (585 $\mathrm{g}$ a.i ha ${ }^{-1}$ of MCPA) was applied at the wheat stem elongation stage, in the 2017/18 growing season. At the 2018/19 growing season, frost occurred on early July helped to control buckwheat and only MCPA (585 $\mathrm{g}$ a.i ha $\left.{ }^{-1}\right)$ was applied at the end of wheat tillering.

\subsection{Cover Crops Studied Variables}

Cover crops evaluations were performed at 18, 32, 46, 57, and 74 days after its sowing (DAS), respectively on the following dates: April $02^{\text {nd }}, 16^{\text {th }}$ and $30^{\text {th }}$ and May $11^{\text {th }}$ and $28^{\text {th }}$ at 2018 . At 2019, these evaluations occurred at 26, 41, 58, 69, and 86 days after its sowing (DAS) respectively on March $28^{\text {th }}$, April $04^{\text {th }}, 29^{\text {th }}$, May $10^{\text {th }}$ and $27^{\text {th }}$.

The assessments were made based on the following features: Plant Height, performed in 10 randomized plants/experimental unit (EU), expressed in $\mathrm{cm}$; green biomass $\left(\mathrm{kg} \mathrm{ha}^{-1}\right)$, determined by collecting plants at two points of one linear meter per experimental plot of each evaluation period; and, dry matter $\left(\mathrm{kg} \mathrm{ha}^{-1}\right)$, determined by samples of green mass oven-dried at $60^{\circ} \mathrm{C}$ until constant mass.

\subsection{Wheat Studied Variables}

Evaluations were carried out just prior wheat harvesting, through the spike length, number of spikes per $1 \mathrm{~m}^{2}$, number of spikelets per spike, number of grains per spikelet, number of grains per spike, 1000-grain weight, and grain yield.

Spike length $(\mathrm{cm})$ was performed in 10 spikes per plot; Number of spikes per square meter 
was obtained by counting the number of spikes in one square meter per plot; Number of spikelet per spike and grain per spike was performed by counting the number of spikelet and grains in 10 spikes per plot; Number of grain per spikelet was obtained by dividing the number of grain per spike by the number of spikelet per spike; 1000-grain weight (g) was determined by counting four subsamples of 250 grains per plot and weighed to obtain the values; and, grain yield $\left(\mathrm{kg} \mathrm{ha}^{-1}\right)$ was assessed by harvesting and threshing $10 \mathrm{~m}^{2}$ of plot, then weighed and corrected to the moisture content for $13 \%$.

\subsection{Statistical Analysis}

Data were collected and subjected to analysis of variance (ANOVA) and when verifying the significant effect among treatments, a complimentary analysis was performed using Scott-Knott test at 5\% probability. For the analysis of the data, Rbio software was used (Bhering, 2017).

\section{Results and Discussion}

Climatic condition plays an important role on field experiments, especially because rainfall shortage, low temperatures and frost risk at this time of the year may direct impact cover crops and wheat yield results. In this way, it was notice a rainfall shortage at April 2018, what may have impaired cover crop development. At 2019, greater amounts or rainfall associated with early sowing allowed a better development and growth of cover crops (Figure 1).

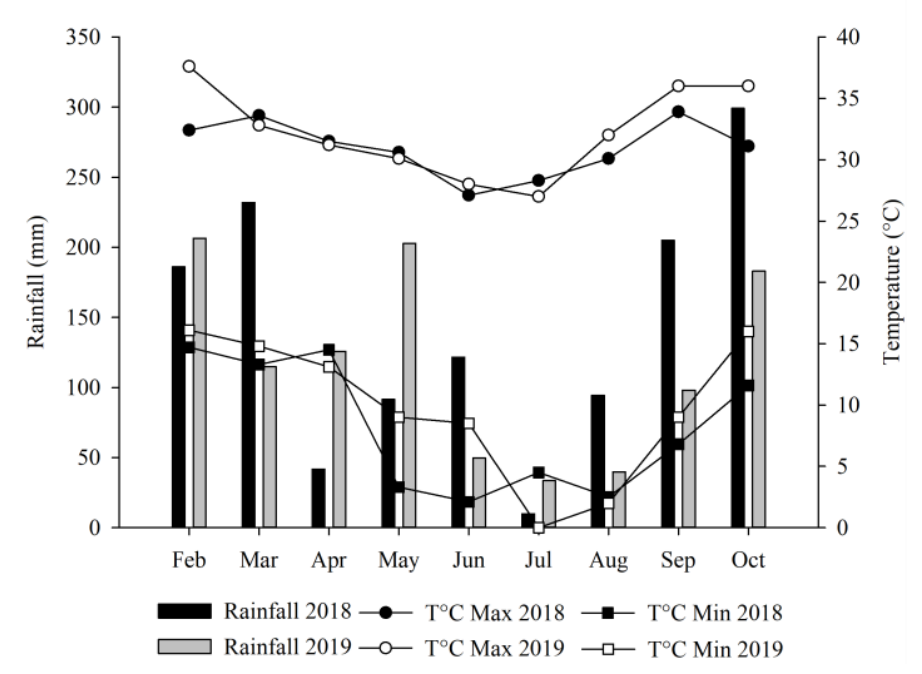

Figure 1 Rainfall $(\mathrm{mm})$, maximum and minimum temperature $\left({ }^{\circ} \mathrm{C}\right)$ observed along the experimental period at 2018 and 2019 growing season (February up to October) -

\section{UTFPR-Campus of Dois Vizinhos}

At winter (June, July and August) was away below its mean average for both years affecting wheat development limiting its tillering, elongation, and floral differentiation. On the other hand, at October, as usual, a period that coincides with the wheat harvest, there was a great volume of rain (> $200 \mathrm{~mm}$ ), which may have affected grain quality and yield.

As important as rainfall, lower temperature noticed at 2018 in relation to 2019 growing 
season may explain lower biomass yield of cover crops. In both years, winter had low temperatures (minimum close to $0{ }^{\circ} \mathrm{C}$ ) which may allowed great wheat yield components differentiation, later on affected by rainfall shortage. At the end of the wheat cycle in 2019, the maximum temperature noticed $\left(>30^{\circ} \mathrm{C}\right.$ ) was approximately $5{ }^{\circ} \mathrm{C}$ higher than 2018 , and this may have had a negative influence on yield and grain quality (Guarienti et al., 2004).

Moreover, it is important to highlight the occurrence of frosts on July 5th and 6th, 2019, which damaged/killed many wheat fields around the research experimental unit, since these fields where sowed earlier in May using cultivars with earlier cycle. At the experimental plots, wheat was at the stem elongation phenological phase, which is resistant to frost and no damage at all was noticed. This strengthens the production risks when wheat agricultural zoning is not respected, which automatically opens up a longer offseason period and enabling the cultivation of cover crops.

When analyzing the behavior of the cover crops growth throughout the evaluation periods within each year, an interaction between species and evaluation period was evidenced for plant height (Table 1) and dry matter yield (Table 2) at both growing seasons (2018 and 2019).

Table 1 Cover crops height sowed on March $03^{\text {rd }}, 2018$ and February $02^{\text {nd }}, 2019$ at different periods after its sowing. Federal Technological University of Paraná

\begin{tabular}{|c|c|c|c|c|c|c|}
\hline \multirow[b]{2}{*}{ Year } & \multirow[b]{2}{*}{ Cover crops } & \multicolumn{5}{|c|}{ Plant Height $(\mathrm{cm})$} \\
\hline & & $\begin{array}{c}18 \mathrm{DAS}^{1} \\
04 / 02^{2}\end{array}$ & $\begin{array}{c}32 \text { DAS } \\
04 / 16\end{array}$ & $\begin{array}{c}46 \text { DAS } \\
04 / 30\end{array}$ & $\begin{array}{c}57 \text { DAS } \\
05 / 11\end{array}$ & $\begin{array}{c}74 \text { DAS } \\
05 / 28\end{array}$ \\
\hline \multirow{4}{*}{2018} & U. brizantha & $20.7 \mathrm{cD}^{3}$ & $23.3 \mathrm{cD}$ & $40.5 \mathrm{dC}$ & $53.5 \mathrm{~dB}$ & $71.0 \mathrm{cA}$ \\
\hline & C. juncea & $19.0 \mathrm{cE}$ & $67.2 \mathrm{aD}$ & $118.0 \mathrm{bC}$ & $140.3 \mathrm{bB}$ & $174.8 \mathrm{aA}$ \\
\hline & P. glaucum & $30.0 \mathrm{bE}$ & $39.5 \mathrm{bD}$ & $140.7 \mathrm{aC}$ & $159.8 \mathrm{aB}$ & $177.5 \mathrm{aA}$ \\
\hline & F. esculentum & $39.5 \mathrm{aB}$ & $73.0 \mathrm{aA}$ & $80.8 \mathrm{cA}$ & $84.0 \mathrm{cA}$ & $86.5 \mathrm{bA}$ \\
\hline \multicolumn{2}{|c|}{ C.V. $(\%)$} & \multicolumn{5}{|l|}{4.77} \\
\hline \multirow{5}{*}{2019} & ----- & $\begin{array}{c}26 \mathrm{DAS} \\
03 / 28\end{array}$ & $\begin{array}{c}41 \text { DAS } \\
04 / 12\end{array}$ & $\begin{array}{c}58 \text { DAS } \\
04 / 29\end{array}$ & $\begin{array}{c}69 \text { DAS } \\
05 / 10\end{array}$ & $\begin{array}{c}86 \text { DAS } \\
05 / 27\end{array}$ \\
\hline & U. brizantha & $11.5 \mathrm{cD}$ & $24.2 \mathrm{cC}$ & $42.2 \mathrm{~dB}$ & $88.1 \mathrm{cA}$ & $88.1 \mathrm{cA}$ \\
\hline & C. juncea & $25.6 \mathrm{bE}$ & $63.7 \mathrm{bD}$ & $116.1 \mathrm{bC}$ & $168.9 \mathrm{bB}$ & $201.6 \mathrm{bA}$ \\
\hline & P. glaucum & $22.6 \mathrm{bE}$ & $71.0 \mathrm{abD}$ & $152.4 \mathrm{aC}$ & $195.9 \mathrm{aB}$ & $210.0 \mathrm{aA}$ \\
\hline & F. esculentum & $41.4 \mathrm{aD}$ & $77.7 \mathrm{aC}$ & $86.6 \mathrm{cB}$ & $93.7 \mathrm{cAB}$ & $95.4 \mathrm{cA}$ \\
\hline \multicolumn{2}{|c|}{ C.V. $(\%)$} & \multicolumn{5}{|l|}{3.92} \\
\hline
\end{tabular}

${ }^{1}$ DAS- Days after sowing; ${ }^{2}$ Date of the year. ${ }^{3}$ Means followed by different lowercase in the columns and uppercase in the rows differ by Scott-Knott test $(\mathrm{p}<0.05)$. 
Table 2 Dry matter of cover crops sowed on March $03^{\text {rd }}$ of 2018 and February $02^{\text {nd }}$ of 2019 at different periods after its sowing. Federal Technological University of Paraná

\begin{tabular}{|c|c|c|c|c|c|c|}
\hline \multirow[b]{2}{*}{ Year } & \multirow[b]{2}{*}{ Cover crops } & \multicolumn{5}{|c|}{ Dry matter $\left(\mathrm{kg} \mathrm{ha}^{-1}\right)$} \\
\hline & & $\begin{array}{c}18 \mathrm{DAS}^{1} \\
04 / 02^{2}\end{array}$ & $\begin{array}{c}32 \text { DAS } \\
04 / 16\end{array}$ & $\begin{array}{c}46 \text { DAS } \\
04 / 30\end{array}$ & $\begin{array}{c}57 \text { DAS } \\
05 / 11\end{array}$ & $\begin{array}{c}74 \text { DAS } \\
05 / 28\end{array}$ \\
\hline \multirow{4}{*}{2018} & U. brizantha & $68 \mathrm{bE}^{3}$ & $603 \mathrm{bD}$ & $1,919 \mathrm{bC}$ & $2,625 \mathrm{cB}$ & $3,632 \mathrm{bA}$ \\
\hline & C. juncea & $58 \mathrm{bE}$ & $441 \mathrm{bD}$ & $1,588 \mathrm{bC}$ & $3,044 \mathrm{cB}$ & $3,801 \mathrm{bA}$ \\
\hline & P. glaucum & $291 \mathrm{aE}$ & $1,735 \mathrm{aD}$ & $3,081 \mathrm{aC}$ & $6,618 \mathrm{aB}$ & $8,537 \mathrm{aA}$ \\
\hline & F. esculentum & $425 \mathrm{aD}$ & $1,574 \mathrm{aC}$ & $3,059 \mathrm{aB}$ & $5,051 \mathrm{bA}$ & $4,404 \mathrm{bA}$ \\
\hline \multicolumn{2}{|c|}{ C.V. $(\%)$} & \multicolumn{5}{|l|}{7.79} \\
\hline \multirow{5}{*}{2019} & & $\begin{array}{c}26 \text { DAS } \\
03 / 28 \\
\end{array}$ & $\begin{array}{c}41 \text { DAS } \\
04 / 12 \\
\end{array}$ & $\begin{array}{c}58 \text { DAS } \\
04 / 29 \\
\end{array}$ & $\begin{array}{c}69 \text { DAS } \\
05 / 10 \\
\end{array}$ & $\begin{array}{c}86 \text { DAS } \\
05 / 27 \\
\end{array}$ \\
\hline & U. brizantha & $85 \mathrm{bD}$ & $516 \mathrm{cD}$ & $2,220 \mathrm{cC}$ & $3,466 \mathrm{bB}$ & $5,710 \mathrm{bA}$ \\
\hline & C. juncea & $335 \mathrm{abE}$ & $1,193 \mathrm{bD}$ & $2,555 \mathrm{cC}$ & $3,822 \mathrm{bB}$ & $5,232 \mathrm{cA}$ \\
\hline & P. glaucum & $399 \mathrm{abE}$ & $1,535 \mathrm{bD}$ & $4,200 \mathrm{bC}$ & $6,121 \mathrm{aB}$ & $9,097 \mathrm{aA}$ \\
\hline & F. esculentum & $708 \mathrm{aE}$ & $2,418 \mathrm{aD}$ & $4,783 \mathrm{aB}$ & $6,345 \mathrm{aA}$ & $3,949 \mathrm{dC}$ \\
\hline \multicolumn{2}{|c|}{ C.V. $(\%)$} & \multicolumn{5}{|l|}{6.08} \\
\hline
\end{tabular}

${ }^{1}$ DAS- Days after sowing; ${ }^{2}$ Date of the year. ${ }^{3}$ Means followed by different lowercase in the columns and uppercase in the rows differ by Scott-Knott test $(\mathrm{p}<0.05)$.

It was found that cover crops grew even at the period of water stress during 2018 (Figure 1), however, at 2019, cover species showed greater growth, as there was no water stress and cover plants were sown earlier, staying a longer period in the field. Concerning to plant height, it stands out at the $2^{\text {nd }}$ evaluation period, the faster initial growth of buckwheat and sunn hemp in the first year and buckwheat, sunn hemp, and pearl millet at the $2^{\text {nd }}$ year (Table 1).

Analyzing the entire cycle, in both years, it is noticed the growth potential of pearl millet and sunn hemp, which grew an average of $2.38 \mathrm{~cm}$ per day in 2018 and $2.39 \mathrm{~cm}$ per day in 2019 , as well as the precocity of buckwheat. This trait is important for weed suppression, avoiding its germination and development due to limited light interception promoted by cover crops (Oliveira et al., 2014). Moreover, it helps position the species since there may be shorter or longer offseason periods between soybean and wheat depending on the region where it is considered as a cover crop option.

As noticed on table 1, pearl millet and sunn hemp showed similar growing habit, with similar height along its development, suggesting that it can be cultivated in consortium, which allow at the same time, seed cost establishment reduction (sunn hemp seed is expensive) and nitrogen biological fixation with a final biomass mix which may be more interesting in terms of nutrient release and soil protection for the next crop.

In both years of evaluation, cover crops showed a high growth rate and final biomass accumulation, being even greater at the 2nd year growing season (2019), due to the fact that species were sowed earlier and had a longer period at field (12 more days). Plus, as noticed of 
Figure 1, this provides a higher temperature and a longer photoperiod (days goes shorter form December to July), increasing the photosynthetic rate and biomass accumulation potential, as reported by Pacheco et al. (2011). This aspect highlights the importance of early sowing, although, March sowing also proved to be effective.

Dry matter yield of pearl millet in the 1 st and $2^{\text {nd }}$ year stands out among other species, where it produced 8,537 and 9,097 $\mathrm{kg} \mathrm{ha}^{-1}$, respectively, with an average accumulation rate of 115 and $105 \mathrm{~kg} \mathrm{DM} \mathrm{ha}^{-1}$ per day. These data corroborate with results reported by Pacheco et al. (2011), where pearl millet produced $8,495 \mathrm{~kg} \mathrm{ha}^{-1}$ at $75 \mathrm{DAS}$, showing the growth potential of this specie.

Among grasses species, brachiaria showed lower initial development and biomass yield than pearl millet, although, after its initial development of photosynthetic apparatus, accumulation rate between the last two evaluated periods was of $132 \mathrm{~kg} \mathrm{DM} \mathrm{ha}^{-1}$ per day, showing to be interesting in longer offseason periods (more than 80 days).

As for sunn hemp, at the first year, it did not express its potential, since its DM increased from 3,801 to $5,232 \mathrm{~kg} \mathrm{ha}^{-1}$ from the 1 st to the $2^{\text {nd }}$ year. Shorter photoperiod at the 1 st year may explain these differences, and as in the fall the photoperiod decreases, the plants tend to shorten its size, producing fewer branches and incorporating less carbon into its tissues (Neto and Campos, 2017). In the other hand, since it is a legume, there is no problem with immobilization of $\mathrm{N}$ for wheat, and this allows being explored for a longer time, as it increased 757 and 1,410 $\mathrm{kg} \mathrm{ha}^{-1}$ between the last two evaluated periods, in 2018 and 2019, respectively.

Neto and Campos (2017), reported DM yields of 1,300 and 2,500 kg ha-1 and 1,100 kg ha-1 and $1,400 \mathrm{~kg} \mathrm{ha}^{-1}$ for sunn hemp and buckwheat sown in late February and mid-March, respectively. Buckwheat specie development showed the fastest cycle associate with intermediate biomass yield. According to Gorgen et al. (2016), buckwheat has a dry matter production potential of up to $5,000 \mathrm{~kg} \mathrm{ha}^{-1}$ and respond well to rainfall and high temperature. This fact is seen in this work, where a minimum temperature below $5{ }^{\circ} \mathrm{C}$ in May, 2018 resulted in a lower, but still very interesting yield of $5,051 \mathrm{~kg} \mathrm{ha}^{-1}$. On the other hand, at 2019, where the minimum temperature was close to $10^{\circ} \mathrm{C}$, the production was $6,345 \mathrm{~kg} \mathrm{ha}^{-1}$.

Plants began blooming in about 35 days from its emergence and its first seeds mature about 15 days later. Thus, it is noticed in Table 2 that there is a decrease in its dry matter yield from the last to the prior evaluation period (from 5,051 to 4,400 at 2018 and from 6,345 to 3,949 $\mathrm{kg} \mathrm{MS} \mathrm{ha}{ }^{-1}$ ) evidencing its rapid development and early senescence.

Taking this into consideration, buckwheat reached its maximum biomass yield around 60 days after its sowing, showing to be a good cover crop option for shorten (45 days long) soybean-wheat offseason. Although, its later seed soil bank emergence on wheat field was very heterogeneous, and many fluxes of emergence occurred, hampering its control, what probably resulted in plant competition with wheat. As reported before, herbicides are still effective to control buckwheat, but three applications were needed at 2018. At colder winter, with frost events, it might not be a problem. 
To highlight this fact, at another experiment nearby, buckwheat grain yield reached value of $1,235 \mathrm{~kg} \mathrm{ha}^{-1}$ at 73 days after sowing (DAS). Considering that the recommended seed rate is around $50-60 \mathrm{~kg} \mathrm{ha}^{-1}$ when a population of 70-80 plants per square meter is desired and that its seed production is way more than that, we advise that buckwheat may become a weed plant into the system and its herbicide management should be done around 50 DAS.

Also, taking this into consideration, it is suggested to use buckwheat as a grain cash crop instead of a cover crop since it will cover the soil, suppress weed at generate income to the farmers instead of became later on a great trouble as a weed plant for wheat. Thus, according to Gorgen et al. (2016), reported that Buckwheat production $(2,301,3,144$ and 4,471 $\mathrm{kg}$ DM $\mathrm{ha}^{-1}$ ) was higher than millet $\left(437,592\right.$ and 2,224 $\left.\mathrm{kg} \mathrm{DM} \mathrm{ha}^{-1}\right)$ at 47, 57 and 67 days after its emergency. The authors reported that Buckwheat produced more forage with high quality than Millet indicating that it can be uses as a forage for animal production. By the away, this opens a new great opportunity of use.

Together these results provide important insights about its cover crops species positioning at the soybean-wheat offseason. Thus, beyond cover crop biomass yield, its effects on wheat crop should be considered.

In this way, table 3 shows that the variable number of spike per square meter did not have a significant difference for both desiccation periods in each year. It is shown that there is no difference on the number of spike per square meter, even noticed some plantability problems at the treatments with brachiaria and P. glaucum desiccated at the wheat sowing day. At the $2^{\text {nd }}$ year, longer period of water shortage may had affected tiller development in all treatments, resulting in a more similar data among treatments. 


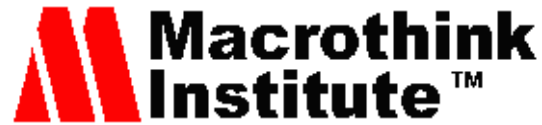

Table 3. Spike length (SL), spikes per $\mathrm{m}^{2}$ (S), grain per spike (GS) and spikelets per spike $(\mathrm{SpS})$ of wheat in relation to cover crops herbicide desiccation periods. Federal Technological University of Paraná- Dois Vizinhos, Brazil

\begin{tabular}{|c|c|c|c|c|c|c|c|c|}
\hline \multirow{2}{*}{ Cover crops } & \multicolumn{2}{|c|}{$\mathrm{SL}(\mathrm{cm})$} & \multicolumn{2}{|c|}{$S$} & \multicolumn{2}{|c|}{ GS } & \multicolumn{2}{|c|}{$\mathrm{SpS}$} \\
\hline & $\mathrm{AD}^{1}$ & DS & $\mathrm{AD}$ & DS & $\mathrm{AD}$ & DS & $\mathrm{AD}$ & DS \\
\hline \multicolumn{9}{|c|}{2018} \\
\hline U. brizantha & $7.6 \mathrm{aA}^{2}$ & $6.9 \mathrm{bB}$ & \multicolumn{2}{|c|}{$485.3^{\text {ns }}$} & \multicolumn{2}{|l|}{$33.2^{\mathrm{ns}}$} & $15.0 \mathrm{aA}$ & $13.3 \mathrm{bB}$ \\
\hline C. juncea & $7.2 \mathrm{bA}$ & $7.2 \mathrm{aA}$ & \multicolumn{2}{|l|}{$570 ; 4$} & \multicolumn{2}{|l|}{34.6} & $13.4 \mathrm{bA}$ & $13.7 \mathrm{bA}$ \\
\hline P. glaucum & $7.6 \mathrm{aA}$ & $7.3 \mathrm{aA}$ & \multicolumn{2}{|l|}{$526 ; 2$} & \multicolumn{2}{|l|}{34,5} & $14.3 \mathrm{bA}$ & $14.1 \mathrm{aA}$ \\
\hline F. esculentum & $7.4 \mathrm{aA}$ & $6.9 \mathrm{bB}$ & \multicolumn{2}{|l|}{561.9} & \multicolumn{2}{|l|}{36.2} & $14.1 \mathrm{bA}$ & $13.4 \mathrm{bA}$ \\
\hline Fallow & $7.6 \mathrm{aA}$ & $7.6 \mathrm{aA}$ & \multicolumn{2}{|l|}{566.4} & \multicolumn{2}{|l|}{34.0} & $13.7 \mathrm{bA}$ & $13.7 \mathrm{bA}$ \\
\hline Mean & 7.5 & 7.2 & $568.7^{\mathrm{ns}}$ & 516.3 & $35.5^{\mathrm{ns}}$ & 34.4 & 14.1 & 13.6 \\
\hline C.V. (\%) & \multicolumn{2}{|l|}{4,70} & \multicolumn{2}{|l|}{14,89} & \multicolumn{2}{|l|}{8,69} & \multicolumn{2}{|l|}{5,14} \\
\hline \multicolumn{9}{|c|}{2019} \\
\hline U. brizantha & \multicolumn{2}{|l|}{$7.0 \mathrm{~b}$} & \multicolumn{2}{|c|}{$409.5^{\mathrm{ns}}$} & \multicolumn{2}{|l|}{$31.3 \mathrm{c}$} & \multicolumn{2}{|l|}{$14.4^{\mathrm{ns}}$} \\
\hline C. juncea & \multicolumn{2}{|l|}{$7.6 \mathrm{a}$} & \multicolumn{2}{|l|}{406.0} & \multicolumn{2}{|l|}{$40.5 \mathrm{a}$} & \multicolumn{2}{|l|}{14.2} \\
\hline P. glaucum & \multicolumn{2}{|l|}{$7.2 \mathrm{~b}$} & \multicolumn{2}{|l|}{411.9} & \multicolumn{2}{|l|}{$37.5 \mathrm{~b}$} & \multicolumn{2}{|l|}{13.5} \\
\hline F. esculentum & \multicolumn{2}{|l|}{$7.2 \mathrm{~b}$} & \multicolumn{2}{|l|}{415.5} & \multicolumn{2}{|l|}{$33.2 \mathrm{c}$} & 13.4 & \\
\hline Fallow & $7.2 \mathrm{~b}$ & & 393.3 & & $33.8 \mathrm{c}$ & & 13.4 & \\
\hline Mean & $7.3^{\text {ns }}$ & 7.2 & $405.1^{\mathrm{ns}}$ & 408.1 & $35.3^{\mathrm{ns}}$ & 34.3 & $13.7^{\mathrm{ns}}$ & 13.8 \\
\hline C.V. (\%) & 3.4 & & 10.19 & & 7.07 & & 6.84 & \\
\hline
\end{tabular}

${ }^{1} \mathrm{AD}$ - anticipated desiccation; DS- desiccation immediately before sowing. ${ }^{2}$ Means followed by different lowercase in the columns and uppercase in the rows differ by Scott-Knott test

$$
(\mathrm{p}<0.05) \text {. }
$$

Spike length increased as the number of spikelets was increased, just as reported by Vesohoski et al. (2011). The same authors report that the number of spikelets per spike is one of the yield components that directly influence grain yield, combined with the number of grains per spikelet and consequently the number of grains per spike.

Further, grain yield components have a relation of tradeoff among its component due to the wheat plasticity. One example is the higher grain per spikelet at the treatment with brachiaria at $1^{\text {st }}$ year at $\mathrm{AD}$ treatment in relation to the other cover crop species. Lower spikes per square meter may have favored this result. Although, at the treatment DS, the number of spikelet reduced which added to a lower spike number (81 spike less per square meter) in relation to the fallow, resulted in a wheat yield reduction of $1,380 \mathrm{~kg} \mathrm{ha}^{-1}$. So even with the yield tradeoff among yield components occurring, these differences can only compensate yield to a certain level.

GRDC (2005) summarized wheat yield components definition with its phenological stage, according to Zadocks cereal growth stage and this knowledge is important to understand the 
influence of the treatments over wheat yield definition. As an example, the number of grain per spikelet is defined at wheat stem elongation phenological phase, and of course, rainfall shortage during this phase may affect this yield component. In the other hand, based on the yield component tradeoff, 1000-grain weight tends to be heavier and vice-versa and so on. Based on this and being final grain yield a result of all yield components, it is possible to infer that even been small, the sum of these differences may result in different final grain yield (Table 4).

Table 4. Grains per spikelet (GSp),1000-grain weight (TGW) and grain yield (Yield) of wheat in relation to cover crops herbicide desiccation periods at 2018 and 2019 growing season. Federal Technological University of Paraná- Dois Vizinhos, Brazil

\begin{tabular}{|c|c|c|c|c|c|c|}
\hline \multirow{2}{*}{ Cover Plants } & \multicolumn{2}{|c|}{ GSp } & \multicolumn{2}{|c|}{ TGW (g) } & \multicolumn{2}{|c|}{ Yield $\left(\mathrm{kg} \mathrm{ha}^{-1}\right)$} \\
\hline & $\mathrm{AD}^{1}$ & DS & $\mathrm{AD}$ & DS & $\mathrm{AD}$ & DS \\
\hline \multicolumn{7}{|c|}{2018} \\
\hline U. brizantha & \multicolumn{2}{|l|}{$2.3^{\mathrm{ns}}$} & \multicolumn{2}{|c|}{$34.0 \mathrm{a}^{2}$} & $3,999.9 \mathrm{aA}$ & $2,643 \mathrm{bB}$ \\
\hline C. juncea & \multicolumn{2}{|l|}{2.5} & \multicolumn{2}{|l|}{$30.4 \mathrm{~b}$} & $3,060.4 \mathrm{bA}$ & $2,913 \mathrm{bA}$ \\
\hline P. glaucum & \multicolumn{2}{|l|}{2.4} & \multicolumn{2}{|l|}{$31.4 \mathrm{~b}$} & $3,366.5 \mathrm{bA}$ & $3,341 \mathrm{aA}$ \\
\hline F. esculentum & \multicolumn{2}{|l|}{2.6} & \multicolumn{2}{|l|}{$33.6 \mathrm{a}$} & $3,2270 \mathrm{bB}$ & $3,743 \mathrm{aA}$ \\
\hline Fallow & \multicolumn{2}{|l|}{2.5} & \multicolumn{2}{|l|}{$35.0 \mathrm{a}$} & $4,023.4 \mathrm{aA}$ & $4,023 \mathrm{aA}$ \\
\hline Mean & $2.5^{\mathrm{ns}}$ & 2.4 & $33.2^{\mathrm{ns}}$ & 32.5 & $3,535.1$ & 3,332 \\
\hline C.V. $(\%)$ & \multicolumn{2}{|l|}{8,26} & \multicolumn{2}{|l|}{5.27} & \multicolumn{2}{|l|}{9.83} \\
\hline \multicolumn{7}{|c|}{2019} \\
\hline U. brizantha & $1.9 \mathrm{cB}$ & $2.4 \mathrm{bA}$ & $29.7 \mathrm{aA}$ & $26.0 \mathrm{~dB}$ & $3,595.7 \mathrm{aA}$ & $2,133.2 \mathrm{cB}$ \\
\hline C. juncea & $2.9 \mathrm{aA}$ & $2.6 \mathrm{aA}$ & $31.3 \mathrm{aB}$ & $34.7 \mathrm{aA}$ & $3,706.0 \mathrm{aA}$ & $3,733.3 \mathrm{aA}$ \\
\hline P. glaucum & $2.5 \mathrm{bA}$ & $2.8 \mathrm{aA}$ & $30.3 \mathrm{aA}$ & $28.3 \mathrm{cB}$ & $3,414.2 \mathrm{bA}$ & $2,825.7 \mathrm{bB}$ \\
\hline F. esculentum & $2.6 \mathrm{bA}$ & $2.4 \mathrm{bA}$ & $30.7 \mathrm{aA}$ & $32.3 \mathrm{bA}$ & $3,378.3 \mathrm{bA}$ & $3,533.4 \mathrm{aA}$ \\
\hline Fallow & $2.5 \mathrm{bA}$ & $2.4 \mathrm{bA}$ & $32.7 \mathrm{aA}$ & $32.2 \mathrm{bA}$ & $3,851.2 \mathrm{aA}$ & $3,762.6 \mathrm{aA}$ \\
\hline Mean & 2.45 & 2.5 & 30.9 & 30.7 & $3,589.4$ & $3,197.5$ \\
\hline C.V. (\%) & \multicolumn{2}{|l|}{7.61} & \multicolumn{2}{|l|}{3.75} & \multicolumn{2}{|l|}{5.31} \\
\hline
\end{tabular}

${ }^{1} \mathrm{AD}$ - anticipated desiccation; DS- desiccation immediately before sowing. ${ }^{2}$ Means followed by different lowercase in the columns and uppercase in the rows differ by Scott-Knott test $(\mathrm{p}<0.05)$.

In the $2^{\text {nd }}$ growing season, the highest number of grains per spike of wheat grown after sunn hemp (40 grains per spike), and consequently the greater number of grains per spikelet (2.9 versus 2.6 at $\mathrm{AD}$ and $\mathrm{DS}$ ) may be possibly related to greater biological nitrogen fixation by the legume, which provides nitrogen for wheat during its cycle helping the plant to increase its yield potential, as reported by Ambrosano et al. (2009).

According to Vesohoski et al. (2011), a good part of the thousand grain mass comes from the redistribution of reserves stored in the stem during the vegetative stage, so factors that compromise the vegetative development of wheat later interfere in the definition of the thousand grain mass (GRDC, 2005). It is noticed at the $2^{\text {nd }}$ year, that the treatments composed 
of grasses (DS) had a lower mass of a thousand grains, a fact that is linked to the immobilization of $\mathrm{N}$ by the grasses (Calonego et al., 2012) and consequently influencing the reduction of wheat yield.

Correlating herbicide management to cover crop biomass yield and wheat yield, it can be noticed in Table 2 and 4 that there is an average biomass increase (two years) from AD to DS of $2,447.5$ and $1,625.5 \mathrm{~kg} \mathrm{ha}^{-1}$ respectively for pearl millet and brachiaria. In this way, it would be important to keep the plants growing in the field, although, this increase in biomass impact wheat grain yield, as shown in table 4.

A wheat grain yield reduction of 1,380 and $1,629 \mathrm{~kg} \mathrm{ha}^{-1}$ between the treatment with brachiaria DS and fallow respectively at 2018 and 2019 suggests that its herbicide management should be anticipated, once at this treatment (herbicide applied 17 days before wheat sowing) these differences were of 24 and $256 \mathrm{~kg} \mathrm{ha}^{-1}$.

It is difficult to explain the wheat yield results at the fallow treatment, once its value was similar or even higher than the treatments with cover crops. Although, it was noticed that higher amounts of brachiaria straw (up to $5 \mathrm{t} \mathrm{ha}^{-1}$ at the $2^{\text {nd }}$ year) difficult wheat plantability and establishment. Later on, its initial development might be impaired due to high $\mathrm{C} / \mathrm{N}$ ratio from straw, which may result in a nitrogen deficiency due to immobilization (Neto and Campos, 2017). Due to it, wheat sow immediately after the brachiaria desiccation is not recommended, especially under longer growing season or high amount of straw.

Pearl millet, at 2018, showed no grain yield difference between the herbicide managements. At 2019 , a difference was found $\left(590 \mathrm{~kg} \mathrm{ha}^{-1}\right)$, what may be explained by the higher amount of dry matter produced and low rainfall amounts near the crop establishment, and perhaps the wheat seed was sowed too shallow, affecting its initial development. In this sense, it is recommended to anticipate the desiccation of pearl millet for sowing wheat, in order to avoid yield and economic losses.

The use of herbicides with a faster desiccation effect such as ammonium glufosinate and haloxyfop-p-methyl (as long as it respects the residual product) may allow the reduction of the period between desiccation and sowing of wheat and consequently allow a greater accumulation of biomass, making cover plants even more suitable.

For sunn hemp, as it is a legume and has a low $\mathrm{C} / \mathrm{N}$ ratio (around 10 according to Rosolem 2016), there was no difference in wheat yield between herbicide management, being recommended to leave sunn hemp producing biomass for a longer period due to higher biomass accumulation. In addition, wheat sowing after sunn hemp is favored, as this cover forms stalks and has no difficulty in cutting due to the double-sided discs of the seeder.

Regarding to buckwheat influence on wheat yield, it is possible to notice on table 4 that at the 1st year, grain yield at the AD was $796 \mathrm{~kg} \mathrm{ha}^{-1}$ lower than the fallow treatment. This result is possible explained by the competition effect between buckwheat and wheat. This yield difference reduced to $280 \mathrm{~kg} \mathrm{ha}^{-1}$ at the DS, since the herbicide metsulfuron-methyl showed better control of buckwheat. At the $2^{\text {nd }}$ year, these differences were lower due to occurrence of frosts, which controlled the buckwheat plants. 


\section{Conclusion}

All the studied cover crops showed a good biomass yield potential and can be used in the soybean-wheat offseason with certain specificities. F. esculentum showed the fastest development cycle and suits well at shorter offseason periods, with 50 days of length. $P$. glaucum showed the highest biomass yield, standing out as the best option for offseason periods of 70 to 80 days. $C$. juncea and $U$. brizantha showed a linear biomass accumulation during the evaluation periods, with high potential for offseason longer than 80 days for its fully development. Although, C. juncea herbicide management can be done at the wheat sowing day while $U$. brizantha and $P$. glaucum anticipated herbicide management showed to be better since wheat yield was affected being lower than the fallow treatment.

\section{Acknowledgements}

The authors are grateful to CAPES (Coordination for the Improvement of Higher Education Personnel) for providing a scholarship for the student, Agrisus and UTFPR-DV.

\section{References}

Ambrosano, E. J. et al. (2009). Nitrogen supply to corn from sunn hemp and velvet bean green manures. Scientia Agricola, 66, 386-394. https://doi.org/10.1590/S0103-90162009000300014

Bhering, L. L. (2017). Rbio: A Tool for Biometric and Statistical Analysis Using the R Platform. Crop Breeding and Applied Biotechnology, 17, 187-190. http://dx.doi.org/10.1590/1984-70332017v17n2s29

Büchi, L. et al. (2018). Importance of cover crops in alleviating negative effects of reduced soil tillage and promoting soil fertility in a winter wheat cropping system. Agriculture, Ecosystems and Environment, 256, 92-104. https://doi.org/10.1016/j.agee.2018.01.005

Calonego, J. C. et al. (2012). Persistência e liberação de nutrientes da palha de milho, braquiária e labe-labe. Bioscience Journal, 28, 770-781. In: http://www.seer.ufu.br/index.php/biosciencejournal/article/view/13885

CQFS (2004). Comissão de química e fertilidade do solo. Manual de adubação e de calagem para os estados do Rio Grande do Sul e Santa Catarina. Porto Alegre, 394 p

Gorgen, A. V. et al. (2016). Productivity and forage quality of buckwheat (Fagopyrum esculentum Moench) and pearl millet (Pennisetum glaucum). Revista Brasileira de Saúde e Produção Animal. 17, 599-607. http://dx.doi.org/10.1590/s1519-99402016000400004

GRDC (2005). Grains, Research \& Development Corporation. Cereal Growth Stages - the link to crop management. $40 \mathrm{p}$

Guarienti, E. M. et al. (2004). Influência das temperaturas máximas e mínimas em características de qualidade industrial e em rendimento de grãos de trigo. Ciência e Tecnologia de Alimentos, 24, 505-515. https://doi.org/10.1590/S0101-20612004000400005

Neto, F. S., \& Campos, A. C. (2017). Plantas de cobertura antecedendo a cultura do trigo. 
Oliveira, J. R. et al. (2014). Grass straw mulching to suppress emergence and early growth of weeds. Planta Daninha, 32, 11-17. http://dx.doi.org/10.1590/S0100-83582014000100002

Pacheco, L. P. et al. (2011). Produção de fitomassa e acúmulo e liberação de nutrientes por plantas de cobertura na safrinha. Pesquisa Agropecuária Brasileira, 46, 17-25. https://doi.org/10.1590/S0100-204X2011000100003

Pires, J. L. F., \& Vargas, L. (2014). Sistema de produção Embrapa. Cultivo do trigo. Plantas daninhas e métodos de controle. Passo Fundo: Embrapa Trigo, 2ed, 25p.

Posse, G. (2018). Impact of land use during winter on the balance of greenhouse gases. Soil Use and Management, 34, 525-532. https://doi.org/10.1111/sum.12458

Rosolem, C. A., Li, Y., \& Garcia R. A. (2016). Soil carbon as affected by cover crops under no-till under tropical climate. Soil Use and Management. 32, 495-503. https://doi.org/10.1111/sum.12309

Vesohoski, F. et al. (2011). Componentes do rendimento de grãos em trigo e seus efeitos diretos e indiretos na produtividade. Revista Ceres, 58, 337-341. http://www.scielo.br/pdf/rceres/v58n3/a14v58n3

\section{Copyright Disclaimer}

Copyright for this article is retained by the author(s), with first publication rights granted to the journal.

This is an open-access article distributed under the terms and conditions of the Creative Commons Attribution license (http://creativecommons.org/licenses/by/4.0/). 